\title{
PENGARUH KUALITAS PELAYANAN TERHADAP KEPUASAN NASABAH KUR PADA PT. BANK MANDIRI (PERSERO) TBK KC MANADO DOTULOLONG LASUT
}

\author{
Esther Nova Kila \\ Paulus Adrian Pangemanan \\ Ellen Grace Tangkere
}

\begin{abstract}
This study aims to determine how satisfaction of customer of KUR PT. Bank Mandiri (Persero) Tbk KC Manado Dotulolong Lasut for five service quality variables. The research was conducted for four months from September to December 2016.The method used is the survey method throught direct interviews with 100 respondents who are KUR customers using descriptive analysis based on the Likert Scale. The results of the study show that service quality is shown through the level of satisfaction of KUR customers at PT. Bank Mandiri KC Manado Dotulolong Lasut is classified as very satisfied which is measured based on five variables, namely tangible, reliability, responsiveness, assurance, and empathy.*jnkd+eprm*
\end{abstract}

Keywords: service quality, customer satisfaction, Bussiness Credit (KUR).

ABSTRAK

Penelitian ini bertujuan untuk mengetahui bagaimana kepuasan nasabah KUR PT. Bank Mandiri (Persero) Tbk KC Manado Dotulolong Lasut terhadap lima variabel kualitas pelayanan. Penelitian dilaksanakan selama empat bulan dari bulan September sampai dengan Desember 2016. Metode yang digunakan adalah metode survei melalui wawancara langsung kepada 100 responden yang menjadi nasabah KUR dengan menggunakan analisis deskriptif berdasarkan skala pengukuran Likert. Hasil penelitian menunjukkan bahwa kualitas pelayanan yang ditunjukkan melalui tingkat kepuasan nasabah KUR pada PT. Bank Mandiri KC Manado Dotulolong Lasut tergolong sangat puas yang diukur berdasarkan lima variabel yaitu bukti fisik (tangible), keandalan (relliability), cepat tanggap (responsiveness), jaminan (assurance), dan kepedulian (emphaty). *jnkd+eprm*

Kata kunci: kualitas pelayanan, kepuasan nasabah, Kredit Usaha Rakyat (KUR).

\section{PENDAHULUAN}

\section{Latar Belakang}

Melihat kondisi sekarang ini di mana persaingan dalam usaha semakin ketat, maka untuk menghadapi situasi dan keadaan yang demikian, pengusaha harus mampu serta cepat dan tanggap dalam mengambil keputusan agar perusahaan yang didirikan dapat berkembang dengan baik. Segala macam cara pelayanan yang sangat menarik ditawarkan demi memanjakan pelanggan, pelayanan yang baik dan tempat bersih serta nyaman untuk para pelanggan setianya.

Era globalisasi sekarang ini, menuntut suatu perusahaan atau badan usaha untuk meningkatkan pelayanan secara profesional sesuai dengan bidangnya masing-masing. Perubahan teknologi dan arus informasi yang sangat cepat telah mendorong perusahaan untuk menghasilkan produk atau jasa yang dapat memenuhi kebutuhan dan keinginan pelanggan, sehingga pelanggan merasa puas dengan apa yang telah mereka dapatkan dari perusahaan atau badan usaha. Banyak cara yang dapat dilakukan perusahaan dalam memenuhi kebutuhan dan keinginan pelanggan, salah satunya yaitu dengan memberikan kesan atau citra yang baik dalam hal produk maupun pelayanan kepada pelanggan (Bandu, 2013).

Hardiyati (2010), menjelaskan bahwa produk atau jasa yang bersaing dalam satu pasar semakin banyak dan beragam akibat keterbukaan pasar. Sehingga terjadilah persaingan antar produsen untuk dapat memenuhi kebutuan pelanggan serta memberikan kepuasan kepada pelanggan secara 
maksimal, karena pada dasarnya tujuan dari suatu bisnis adalah untuk menciptakan rasa puas pada pelanggan. Salah satu tindakan untuk memuaskan pelanggan adalah dengan cara memberikan pelayanan kepada pelanggan dengan sebaik-baiknya.

Kualitas pelayanan yang diberikan merupakan kinerja terpenting oleh perusahaan bagi kepuasan pelanggan. Perusahaan harus memperhatikan hal-hal penting bagi pelanggan, supaya mereka merasakan kepuasan sebagaimana yang diharapkan. Menurut Supranto dalam Yulinda (2013), kepuasan pelanggan adalah apabila pelanggan mendapat apa yang mereka inginkan sesuai dengan kebutuhan mereka.

Lembaga perbankan yang merupakan lembaga keuangan menawarkan produk jasa seperti, simpanan giro, deposito, tabungan, fasilitas kredit, investasi, perumahan dan sebagainya yang sangat mempermudah masyarakat dalam memenuhi kebutuhannya. Bank juga merupakan alat penghubung bagi masyarakat yang memiliki kelebihan dana dan kekurangan dana dimana yang memilliki kelebihan dana akan menyimpan sejumlah dana di bank dan yang memiliki kekurangan dana akan meminjam sejumlah dana di bank.

Aktivitas utama dalam perbankan adalah penyaluran kredit atau pembiayaan. Bank dapat menjalankan usahanya dengan baik apabila menyalurkan kredit dengan lancar. Melihat hal tersebut, maka pemerintah bekerjasama dengan perbankan untuk mengeluarkan suatu kebijakan baru yang dapat membantu masyarkat atau pelaku Usaha Mikro, Kecil dan Menengah (UMKM) dalam rangka meningkatkan usahanya. Pola penyaluran atau pembiyaan tersebut dinamakan Kredit Usaha Rakyat (KUR). KUR kemudian disalurkan kepada enam bank yang ada di Indonesia, salah satunya adalah PT. Bank Mandiri (Persero) Tbk.

PT. Bank Mandiri (Persero) Tbk KC Manado Dotuolong Lasut merupakan salah satu bank milik pemerintah yang memiliki jaringan usaha seluruh wilayah Indonesia dan memiliki produk yang dapat bersaing baik dari segi teknologi maupun pendekatan kepada masyarakat. Bank ini menyediakan pinjaman pada sektor agribisnis seperti, Kredit Usaha Mikro (KUM), Kredit Ketahanan Pangan dan Energi (KKP-E) dan Kredit Pengembangan Energi Nabati dan Revitalisasi Perkebunan (KPEN-RP).

Kepuasan pelanggan terhadap pelayanan kredit merupakan hal yang perlu mendapat perhatian dari penyelenggara layanan kredit dalam menjalankan peranannya selaku pelayanan kredit. Untuk proses peminjaman produk Kredit Usaha Rakyat sendiri, masih banyak ditemukan keluhan nasabah terhadap proses pelayanan dalam pengajuannya. Beberapa proses yang sering dikeluhkan oleh para nasabah seperti kurangnya informasi tentang prosedur pelayanan KUR, proses verifikasi yang terlalu berbelit-belit dan aturan tentang waktu pencairan kreditnya yang tidak pasti.

Pada saat melakukan transaksi, kualitas pelayanan merupakan tingkat paling unggul yang paling diharapkan dan pengendalian atas tingkat tersebut akan memenuhi harapan nasabah. Jika bank tidak mampu memberikan layanan terbaik kepada nasabah, maka dikhawatirkan akan timbul masalah berupa pemutusan hubungan bisnis dengan pihak bank. Untuk itulah, kualitas pelayanan memegang peranan penting dalam mempengaruhi nasabah untuk melakukan transaksi.

\section{Rumusan Masalah}

Rumusan masalah dalam penelitian ini adalah bagaimana pengaruh kualitas pelayanan terhadap kepuasan nasabah KUR PT. Bank Mandiri (Persero) Tbk KC Manado Dotulolong Lasut?

\section{Tujuan Penelitian}

Tujuan dari penelitian ini adalah mengetahui kepuasan nasabah KUR PT. Bank Mandiri (Persero) Tbk KC Manado Dotulolong Lasut terhadap lima variabel dari kualitas pelayanan yaitu bukti fisik (tangible), keandalan (reliability), cepat tanggap (responsiveness), jaminan (assurance), dan kepedulian (emphaty)

\section{Manfaat Penelitian}

Manfaat dari penelitian ini adalah:

a. Sebagai bahan referensi untuk penelitian di bidang kualitas pelayanan jasa di masa yang akan datang dan sebagai bahan untuk menambah pustaka di bidang pemasaran berdasarkan penerapan yang ada dalam kenyataan.

b. Dapat di jadikan sebagai sumber informasi bagi pihak bank dalam usaha meningkatkan kualitas pelayanan, supaya lebih memuaskan nasabah dan untuk mempertahankan tingkat pelayanan yang menguntungkan dimasa kini dimasa mendatang.

\section{METODE PENELITIAN}

\section{Waktu dan Tempat Penelitian}

Penelitian ini dilaksanakan selama empat bulan dari bulan September sampai dengan Desember 2016 yang dimulai dari persiapan sampai penyusunan laporan penelitian. Tempat penelitian adalah PT. Bank Mandiri (Persero) Tbk KC Unit Mikro Dotulolong Lasut Manado. 


\section{Metode Pengumpulan Data}

Data yang digunakan dalam penelitian ini adalah data primer yaitu wawancara langsung dengan nasabah KUR dan data sekunder yaitu data yang diambil dari PT. Bank Mandiri (Persero) Tbk KC Manado Dotulolong Lasut yang berkaitan dengan penelitian. Metode pengumpulan data dilakukan dengan cara memberikan kuisioner kepada responden atau nasabah untuk diisi kemudian lembar kuisioner dikumpulkan, diolah dan kemudian dianalisis.

\section{Metode Pengambilan Sampel}

Metode pengambilan sampel dalam penelitian ini mengunakan metode metode purposive sampling. Teknik penentuan sampel berdasarkan kebetulan, Penelitian ini mengambil sampel nasabah Kredit Usaha Rakyat PT. Bank Mandiri (Persero) Tbk KC Unit Mikro Dotulolong Lasut Manado. Untuk menentukan ukuransampel penelitian dari populasi tersebut dapat digunakan rumus 15 atau 20 kali variabel bebas (Joseph Hair dalam Hardiyati, 2010), jadi di dapat hasil sebagai berikut:

Rumus Hair adalah:

$$
\mathrm{n}=(15-20) \times \mathrm{k}
$$

Ket. $\mathrm{n} \quad=$ sampel (jumlah koresponden)

$15-20=$ jumlah pertanyaan menurut Hair

$\mathrm{k}=$ jumlah variabel bebas

$20 \times 5$ (jumlah variabel bebas) $=100$

Sehingga berdasarkan perhitungan di atas, maka jumlah sampel yang digunakan adalah sebesar 100 responden.

\section{Konsep Pengukuran Variabel}

Adapun yang menjadi konsep pengukuran variabel dalam penelitian ini adalah sebagai berikut:

a. Karakteristik Responden

1. Jenis Kelamin : Laki-laki / Perempuan

2. Umur : Usia responden (tahun)

3. Tingkat Pendidikan : Lamanya responden mengenyam pendidikan

4. Pekerjaan : Profesi dari responden saat diwawancara

b. Untuk mengukur kualitas pelayanan yang diberikan oleh pihak bank, adapun variabelvariabel yang diukur sebagai berikut :

1. Bukti Fisik (Tangibles)

2. Keandalan (Reliability)

3. Daya Tanggap (Responsiveness)

4. Jaminan (Assurance)

5. Kepedulian (Emphaty)

\section{Metode Analisis Data}

Analisis data yang digunakan dalam penelitian ini merupakan analisis deskriptif yang di analisis dengan menggunakan skala pengukuran sikap atau Skala Likert, yaitu pemberian skor tertinggi dan terendah dari masing-masing jawaban pertanyaan yang akan diajukan kepada responden. Dalam penelitian ini ditentukan skor tertingggi dan terendah. Jawaban pertanyaan tertinggi diberi nilai 5 sedangkan jawaban terendah diberi nilai 1. Jawaban diantara kedua skala tersebut disesuaikan dengan jumlah jawaban yang ada, untuk pertanyaan :

$$
\begin{array}{ll}
\text { SP }: \text { Sangat Puas } & =\text { diberi nilai } 5 \\
\mathrm{P}: \text { Puas } & =\text { diberi nilai } 4 \\
\mathrm{~N}: \text { Netral } & =\text { diberi nilai } 3 \\
\mathrm{KP}: \text { Kurang Puas } & =\text { diberi nilai } 2 \\
\mathrm{TP}: \text { Tidak Puas } & =\text { diberi nilai } 1
\end{array}
$$

Dengan cara perhitungan skor masingmasing pertanyaan. Jumlah Skor Tiap Kriterium= Capaian Skor x Jumlah Responden, jadi

$$
\begin{aligned}
& \text { S5 }=5 \times 100=500 \\
& \text { S } 4=4 \times 100=400 \\
& \text { S3 }=3 \times 100=300 \\
& \text { S2 }=2 \times 100=200 \\
& \text { S1 }=1 \times 100=100
\end{aligned}
$$

Jumlah skor ideal untuk setiap intem pertanyaan skor tertinggi $=500$ (sangat puas), jumlah skor terendah $=100$ (sangat tidak puas). Dengan interpretasi nilai:

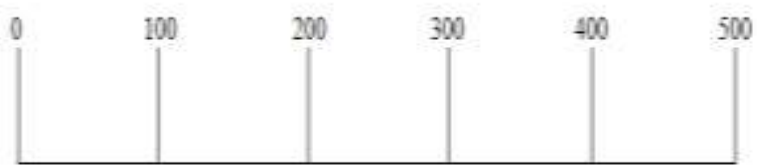

Gambar 1. Intopretasi Nai dari Vasing-masing Pertanyan

Cara perhitungan skor keseluruhan untuk mengetahui tingkat kepuasan: Jumlah Skor seluruh Kriterium = Capaian Jumlah Skor $\mathrm{x}$ Jumlah Responden $x$ Jumlah instrument pertanyaan.

$$
\begin{aligned}
& \text { S5 }=5 \times 100 \times 20=10.000 \\
& S 4=4 \times 100 \times 20=8.000 \\
& S 3=3 \times 100 \times 20=6.000 \\
& S 2=2 \times 100 \times 20=4.000 \\
& S 1=1 \times 100 \times 20=2.000
\end{aligned}
$$

Jumlah skor ideal untuk keseluruhan pertanyaan $=10.000$ (sangat puas), jumlah skor terendah $=2.000$ (tidak puas).

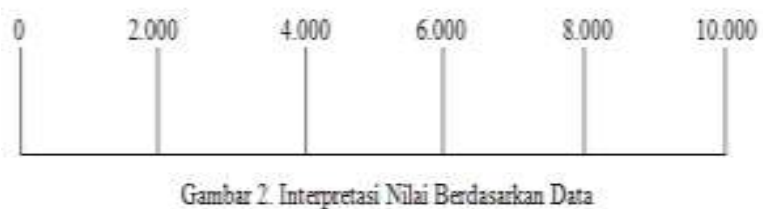


Analisis data yang digunakan merupakan analisis deskriptif yang di analisis dengan menggunakan skala pengukuran skala Likert. Adalah sebagai berikut.

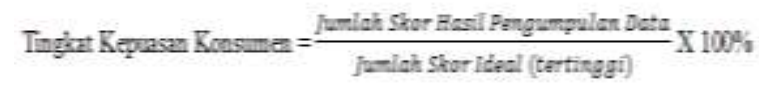

Dengan interpretasi:

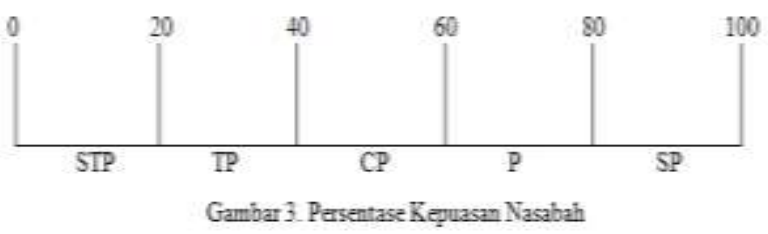

Keterangan: Kriteria interpretasi skor Angka 0\%-20\% = Tidak Puas

Angka $21 \%-40 \%=$ Kurang Puas

Angka $41 \%-60 \%=$ Netral

Angka $61 \%-80 \%=$ Puas

Angka $81 \%-100 \%=$ Sangat Puas

\section{HASIL DAN PEMBAHASAN}

\section{Deskripsi Umum Objek Penelitian}

PT. Bank Mandiri (Persero) Tbk. yang selanjutnya disebut Bank Mandiri didirikan di Negara Republik Indonesia pada tanggal 2 Oktober 1998 berdasarkan Peraturan Pemerintah No.75 tahun 1998 tanggal 1 Oktober 1998. Akta pendirian telah disahkan oleh Menteri Kehakiman berdasarkan Surat Keputusan No. C2- 16561 HT.01.Th98 tanggal 2 Oktober 1998, serta diumumkan pada tambahan No. 6859 dalam berita Negara Republik Indonesia No.97 tanggal 4 Desember 1998. Pada bulan Juli 1999, Bank Mandiri didirikan melalui pengalihan hampir seluruh Saham Pemerintah Republik Indonesia yaitu PT. Bank Bumi Daya (Persero), PT. Bank Dagang Negara (Persero), PT. Bank Expor Impor Indonesia (Persero), dan PT. Bank Pembangunan Indonesia dan Setoran Tunai Pemerintah.

Lokasi penelitian ini bertempat pada Kantor PT. Bank Mandiri (Persero) Tbk KC Manado Dotulolong Lasut yang beralamatkan di Jl. Dotulolong Lasut No. 15 Manado.

\section{Kredit Usaha Rakyat (KUR) PT. Bank Mandiri (Persero) Tbk}

KUR Bank Mandiri merupakan kredit yang diberikan oleh Bank Mandiri untuk membiayai usaha produktif mikro, kecil, menengah dan koperasi yang layak atau feasible namun belum bankable untuk modal kerjanya. KUR Mandiri juga bisa berupa kredit investasi melalui pola pembiayaan yang diberikan baik secara langsung maupun tidak langsung dan dijamin oleh Lembaga Penjamin Kredit. KUR Mandiri bisa dikatakan sebagai Bank yang memberikan bunga kredit paling rendah dibandingkan bank konvensional lainnya. Sehingga banyak orang yang lebih mengajukan KUR ke bank Mandiri daripada bank lainnya.

Melalui Bank Mandiri para nasabah bisa mengajukan pinjaman hingga maksimal Rp 500 juta, sementara suku bunganya $9 \%$ per tahunnya. Jika Anda ingin mengajukan pinjaman sebaiknya disesuaikan dengan kebutuhan usaha Anda. Jangan sampai terlalu besar hingga menyulitkan Anda untuk membayar angsurannya. Berikut cara agar bisa lancar dalam mengajukan dana KUR.

1. Pastikan Anda tidak sedang dalam pembiayaan KUR baik dengan Bank Mandiri maupun lembaga keuangan lainnya.

2. Pastikan usaha yang Anda jalankan umurnya minimal enam bulan. Tentunya untuk mendapatkan KUR bukan usaha yang masih baru apalagi usaha yang masih dalam tahap rencana.

3. Pastikan usaha Anda tersebut sehat. Maksudnya usaha Anda memang mengalami keuntungan dan tidak rugi. Sehatnya usaha Anda bisa terlihat dari laporan keuangan Anda.

4. Siapkan jaminan. Karena bisa jadi Bank Mandiri meminta jaminan atau agunan sebelum mencairkan KUR yang dibutuhkan oleh usaha Anda.

Jika Anda ingin mengajukan KUR Bank Mandiri maka syarat utamanya Anda telah memiliki usaha yang berkala minimal enam bulan. Sementara persyaratan lainnya yaitu:

a. Tidak termasuk dalam daftar hitam Bank Indonesia

b. Foto copy KTP, Kartu Keluarga, Surat Nikah atau Cerai

c. Photo $4 \times 6$ suami istri

d. Surat Keterangan Usaha

e. Khusus kredit di atas Rp 50 juta maka disyaratkan memiliki NPWP

f. Agunan BPKB Motor, Mobil AJB, SHM, SHGB.

\section{Karakteristik Responden}

Jumlah responden dalam penelitian ini berjumlah 100 responden penerima Kredit Usaha Rakyat (KUR) pada PT. Bank Mandiri (Persero) Tbk KC Unit Mikro Dotulolong Lasut.

\section{Berdasarkan Jenis Kelamin}

Adapun distribusi responden dalam penelitian ini dapat dijelaskan berdasarkan jenis kelamin dan hasil yang diperoleh dapat dilihat pada Tabel 1 . 
Tabel 1. Karakteristik Responden Berdasarkan Jenis Kelamin

\begin{tabular}{|c|c|c|c|}
\hline \multirow{2}{*}{ No } & \multirow{2}{*}{ Jenis Kelamin } & \multicolumn{2}{|c|}{ Jumlah } \\
\hline & & Responden (Orang) & Persentase $(\%)$ \\
\hline 1 & Pria & 57 & 57,0 \\
\hline \multirow[t]{2}{*}{2} & Wanita & 43 & 43,0 \\
\hline & Total & 100 & 100,0 \\
\hline
\end{tabular}

Sumber : Diolah dari data primer, 2017

Berdasarkan Tabel 1, menunjukkan bahwa sebagian besar reponden yaitu pria sebanyak 57 responden dengan persentase $57,0 \%$ sedangkan responden wanita sebanyak 43 dengan jumlah persentase sebesar $43,0 \%$.

\section{Berdasarkan Umur}

Adapun distribusi responden dalam penelitian ini dapat dijelaskan berdasarkan umur dan hasil yang diperoleh dapat dilihat sebagai berikut.

\begin{tabular}{cccc}
\multicolumn{5}{c}{ Tabel 2. Karakteristik Responden Berdasarkan Umur } \\
\hline \multirow{2}{*}{ No } & Umur & \multicolumn{2}{c}{ Jumlah } \\
& (Tahun) & Responden (Orang) & Persentase (\%) \\
\hline 1 & $21-30$ & 16 & 16,0 \\
2 & $31-40$ & 35 & 35,0 \\
3 & $41-50$ & 31 & 31,0 \\
4 & $\geq 51$ & 18 & 18,0 \\
\hline & Total & 100 & 100,0 \\
\hline
\end{tabular}

Sumber : Diolah dari data primer, 2017

Berdasarkan Tabel 2, menunjukkan bahwa jumlah responden terbanyak pada umur antara 31 - 40 tahun yaitu 35 orang dengan persentase sebesar $35,0 \%$ Sedangkan jumlah responden terendah ada pada umur antara 21 30 tahun sebanyak 16 orang dengan responden $16,0 \%$. Hal ini menunjukkan bahwa responden memiliki usia yang termasuk aam golongan usia produktif, diharapkan mampu mengembangkan usahanya dengan baik dan memiliki tingkat kematangan berpikir dalam menjalankan usahanya.

\section{Berdasarkan Pendidikan Terakhir}

Adapun distribusi responden dalam penelitian ini dapat dijelaskan berdasarkan pendidikan terakhir dan hasil yang diperoleh dapat dilihat sebagai berikut:

Tabel 3. Karakteristik Responden Berdasarkan Pendidikan Terakhir

\begin{tabular}{clcc}
\hline \multirow{2}{*}{ No } & \multirow{2}{*}{$\begin{array}{c}\text { Pendidikan } \\
\text { Terakhir }\end{array}$} & \begin{tabular}{c} 
Jumlah \\
\cline { 3 - 4 }
\end{tabular} & \multicolumn{2}{c}{ (Orang) } & Persentase (\%) \\
\hline 1 & SD & 22 & 22,0 \\
2 & SMP & 19 & 19,0 \\
3 & SMA & 47 & 47,0 \\
4 & PERGURUAN & 12 & 12,0 \\
& TINGGI & & 100,0 \\
\hline
\end{tabular}

Berdasarkan Tabel 3, dapat dijelaskan bahwa dari 100 responden yang ada terdapat yang paling tinggi yaitu pada tingkat pendidikan SMA sebanyak 47 orang dengan tingkat persentase sebesar $47 \%$. Sedangkan untuk yang paling rendah terdapat pada tingkat pendidikan PERGURUAN TINGGI yaitu 12 orang dengan tingkat persentase sebesar $12 \%$. Hal ini menunjukkan bahwa kredit yang diberikan oleh pihak bank perlu menyikapinya dengan terus menyesuaikan kebijakan pelayanan.

\section{Berdasarkan Pekerjaan}

Adapun distribusi responden dalam penelitian ini dapat dijelaskan berdasarkan pekerjaan dan hasil yang diperoleh dapat dilihat sebagai berikut:

Tabel 4. Karakteristik Responden Berdasarkan Pekerjaan

\begin{tabular}{clcc}
\hline No & \multicolumn{1}{c}{ Pekerjaan } & $\begin{array}{c}\text { Jumlah } \\
\text { Responden } \\
\text { (Orang) }\end{array}$ & $\begin{array}{c}\text { Persentase } \\
(\%)\end{array}$ \\
\hline 1 & Pelajar/ Mahasiswa & 12 & 12,0 \\
2 & PNS / Karyawan & 35 & 35,0 \\
3 & Wiraswasta & 39 & 39,0 \\
4 & Lain-lain & 14 & 14,0 \\
\hline & Total & 100 & 100,0 \\
\hline Sumber : Diolah dari data primer, 2017
\end{tabular}

Sumber : Diolah dari data primer, 2017

Dari data Tabel 4, diketahui karakteristik responden yang paling dominan yaitu Wiraswasta sebanyak 39 orang atau 39\%, diikuti PNS / Kayawan sebanyak 35 orang atau $35 \%$, selanjutnya lain-lain 14 orang atau14\% dan terakhir adalah pelajar / mahasiswa sebanyak 12 orang atau $12 \%$.

\section{Perhitungan Skor Deskripsi Variabel Bukti Fisik}

Analisis deskripsi jawaban responden tentang variabel bukti fisik didasarkan pada jawaban nasabah atau pernyataan-pernyataan yang terdapat dalam kusioner yang disebarkan pada nasabah. Variasi jawaban nasabah untuk bukti fisik dapat dilihat pada Tabel 5 .

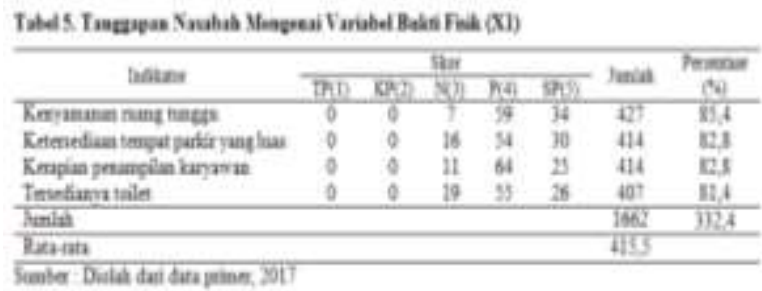

Dari hasil Tabel 5. Menunjukkan bahwa indikator kenyamanan ruang tunggu memiliki kontribusi tertinggi dengan skor 427. Hal ini disebabkan ruang tunggu yang ada menurut nasabah sudah baik. Diikuti dengan indikator ketersediaan tempat parkir yang luas dan kerapian penampilan 
karyawan dengan skor yang sama yaitu 414 . Sedangkan skor yang terendah ada pada indikator tersedianya toilet sebesar 407, sehingga harus ada perbaikan tempat toilet karena hal tersebut berkaitan erat hubungannya dengan kemampuan perusahaan dalam menunjukkan keberadaan fasilitas fisik kepada nasabah.

\section{Perhitungan Skor Deskripsi Variabel Keandalan}

Analisis deskripsi jawaban responden tentang variabel keandalan didasarkan pada jawaban nasabah yang terdapat dalam kusioner yang disebarkan pada nasabah. Variasi jawaban nasabah untuk bukti fisik dapat dilihat pada Tabel 6.

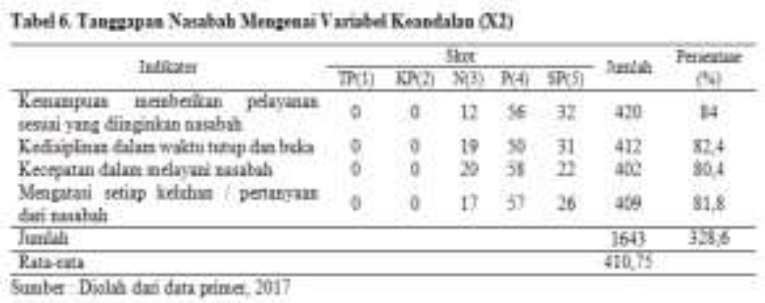

Tabel 6. Menunjukkan bahwa skor yang paling tinggi ada pada indikator kemampuan karyawan memberikan pelayanan sesuai yang diinginkan nasabah sebesar 420. Hal ini disebabkan nasabah merasa puas dengan ketepatan janji dari karyawan bank karena karyawan memberikan layanan kepada konsumen sesuai dengan yang dijanjikan. Untuk skor yang paling rendah yaitu pada skor 402 pada indikator kecepatan dalam melayani nasabah.

\section{Perhitungan Skor Deskripsi Variabel Daya Tanggap}

Analisis deskripsi jawaban responden tentang variabel daya tanggap didasarkan pada jawaban nasabah atau pernyataan-pernyataan yang terdapat dalam kusioner yang disebarkan pada nasabah. Variasi jawaban nasabah untuk bukti fisik dapat dilihat pada Tabel 7 .

\begin{tabular}{|c|c|c|c|c|c|c|c|}
\hline \multirow{2}{*}{ talikuter } & \multicolumn{5}{|c|}{5 kan } & \multirow{2}{*}{ fenial } & \multirow{2}{*}{$\begin{array}{l}\text { Pasement } \\
\text { (4) }\end{array}$} \\
\hline & $T P(1)$ & $\mathrm{k} 3(2)$ & șin & (P) & 52155 & & \\
\hline $\begin{array}{l}\text { Ketequtun dalum memberikan } \\
\text { pelayanan bupi nasabah }\end{array}$ & 0 & 0 & 19 & 59 & $n$ & 402 & 80,6 \\
\hline 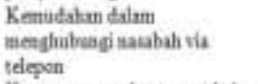 & 0 & 0 & 21 & 52 & 20 & 392 & 78,4 \\
\hline $\begin{array}{l}\text { Karyawan menbenth nusbah } \\
\text { dalam kelenglapan } \\
\text { administrai }\end{array}$ & 0 & 0 & 13 & 61 & 26 & 413 & 82.6 \\
\hline 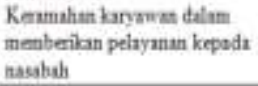 & 0 & 0 & 20 & 55 & 25 & 405 & 81,0 \\
\hline Jumlah & & & & & & 1617 & 3226 \\
\hline Rata tata & & & & & & 403.25 & \\
\hline
\end{tabular}

Dari Tabel 7. Menunjukkan bahwa indikator karyawan membantu konsumen dalam kelengkapan administrasi memiliki skor 413 yang merupakan paling tinggi. Hal ini ditunjang karena karyawan sangat membantu konsumen dalam kelengkapan administrasi, contohnya kelengkapan persyaratan kredit. Sedangkan skor yang terendah ada pada indikator kemudahan dalam menghubungi nasabah via telepon dengan interpretasi puas.

\section{Perhitungan Skor Deskripsi Variabel Jaminan (X4)}

Analisis deskripsi jawaban responden tentang variabel jaminan didasarkan pada jawaban nasabah atau pernyataan-pernyataan yang terdapat dalam kusioner yang disebarkan pada nasabah. Variasi jawaban nasabah untuk bukti fisik dapat dilihat pada Tabel 8 .

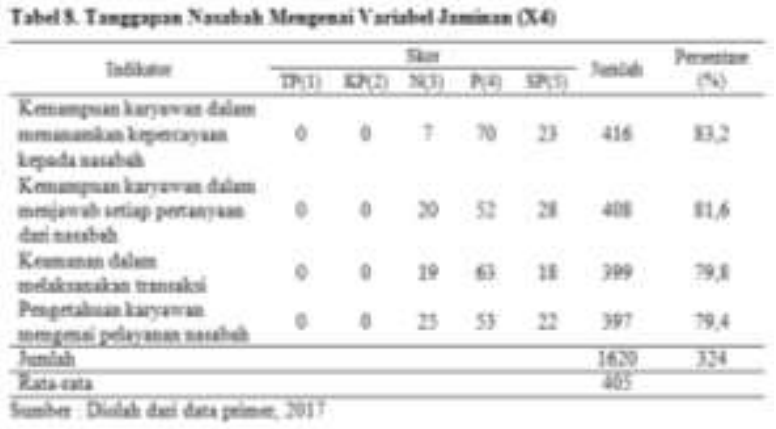

Dari hasil Tabel 8, dapat dilihat bahwa indikator kemampuan karyawan dalam menanamkan kepercayaan kepada nasabah sebesar 416. Hal ini ditunjang dari nasabah merasa puas dengan kesopanan karyawan dalam pelayanan. Untuk indikator yang memiliki skor yang rendah 397 adalah pengetahuan karyawan mengenai pelayanan nasabah.

\section{Perhitungan Skor Deskripsi Variabel Kepedulian (X5)}

Analisis deskripsi jawaban responden tentang variabel kepedulian didasarkan pada jawaban nasabah. Variasi jawaban nasabah untuk bukti fisik dapat dilihat pada Tabel 9.

\begin{tabular}{|c|c|c|c|c|c|c|c|}
\hline Intavarar & \multicolumn{5}{|c|}{ Fis } & Nata & $\begin{array}{c}\text { Pentala: } \\
(\%)\end{array}$ \\
\hline Karyw an mempetsañ & moi) & XN27 & N(1) & F(1) & SN(S) & & \\
\hline 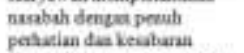 & 0 & 0 & 24 & 61 & 15 & 391 & 38,2 \\
\hline $\begin{array}{l}\text { Kepentingas kasabah sedali } \\
\text { dpentrikas }\end{array}$ & 0 & 0 & 30 & 46 & 24 & 394 & 28,8 \\
\hline $\begin{array}{l}\text { Kemampuau kaysosa dalam } \\
\text { memuhami kebunitas } \\
\text { asaahah }\end{array}$ & 0 & 0 & 26 & $\$ 2$ & 23 & 396 & 79,2 \\
\hline 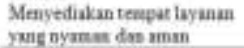 & 0 & 0 & 16 & 41 & 36 & 420 & 14,0 \\
\hline funlo & & & & & & TEO & 3902 \\
\hline Ratarata & & & & & & 100.23 & \\
\hline
\end{tabular}


Berdasarkan Tabel 9 menunjukkan bahwa indikator menyediakan tempat layanan yang nyaman dan aman memiliki skor sebesar 420. Hal ini ditunjang dengan nasabah merasa sangat puas dengan sikap dari karyawan yang menyediakan tempat layanan yang nyaman bagi konsumen karena pihak bank memberikan tempat layanan dengan ruangan yang sejuk. Untuk indikator ini mempunyai interpretasi sangat puas. Dan untuk skor terendah pada skor 391 untuk indikator karyawan memperlakukan nasabah penuh perhatian dan kesabaran.

\section{Rekapitulasi Total Skor, Tingkat Kepuasan dan Interpretasi}

Dalam Tabel 10 menunjukkan rekapitulasi jumlah skor, tingkat kepuasan dan interpretasi dari segi bukti fisik, keandalan, daya tanggap, jaminan dan kepedulian yang diberikan oleh PT. Bank Mandiri (Persero) Tbk KC Manado Dotulolong Lasut.

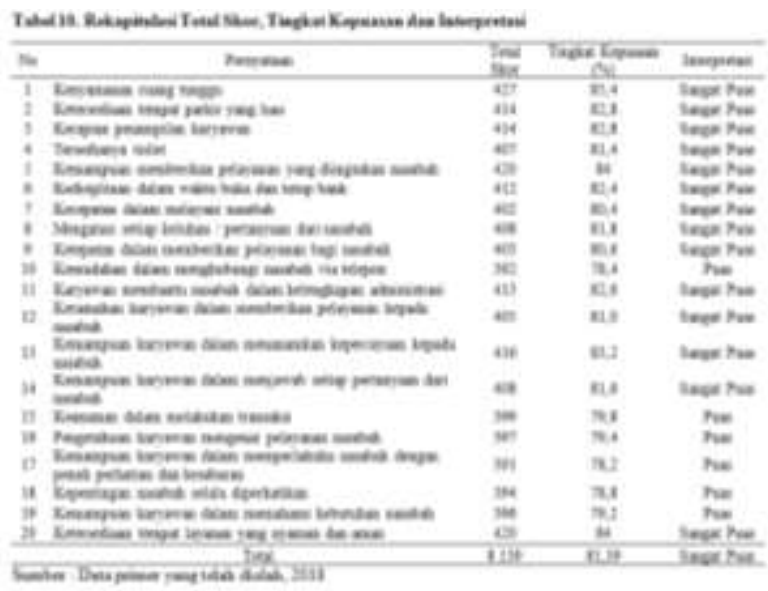

Jumlah skol ideal untuk semua pertanyaan = 10.00 (sangat puas), jumlah skor terendah $=2000$ (sangat tidak puas). Berdasarkan data yang diperoleh dari 20 pertanyaan yang diberikan kepada 100 responden, maka diperoleh total skor 8.139, dengan indeks tingkat kepuasan pengunjung sebagai berikut:

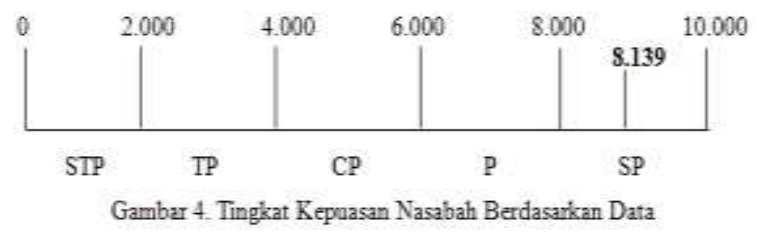

Secara persentase, tingkat kepuasan nasabah KUR pada PT. Bank Mandiri (Persro) Tbk KC Manado Dotulolong Lasut adalah sebagai berikut:

$$
\begin{aligned}
\text { Tingkat Kepuasan Konsumen } & =\frac{8.139}{10.000} \times 100 \% \\
& =81,39 \%
\end{aligned}
$$

Dengan indeks tingkat kepuasan pengunjung yaitu:

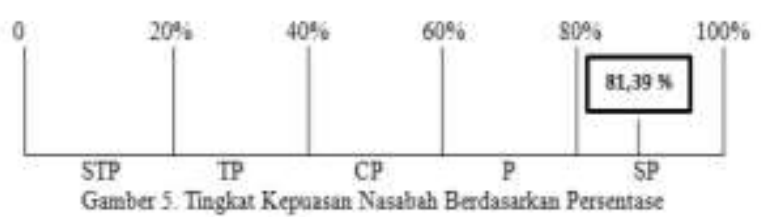

Hasil perhitungan diatas menunjukan angka indeks persepsi konsumen Kredit Usaha Rakyat (KUR) terhadap pelayanan pada bank Mandiri KC Manado Dotulolong Lasut sebesar $81,39 \%$, artinya konsumen secara umum tergolong sangat puas. Untuk meningkatkan lagi kepuasan nasabahnya, maka pihak bank harus meningkatkan pelayanan melalui kelima variabel diatas yaitu; bukti fisik (tangible), keandalan (relliability), cepat tanggap (responsiveness), jaminan (assurance), dan kepedulian (emphaty).

\section{KESIMPULAN DAN SARAN}

\section{Kesimpulan}

Berdasarkan hasil penelitian yang telah dilakukan dan telah diuraikan pada bab sebelumnya, maka dapat diambil kesimpulan bahwa kualitas pelayanan terhadap kepuasan nasabah KUR pada bank Mandiri KC Manado Dotulolong Lasut tergolong sangat puas berkaitan dengan kelima variabel yang di teliti yaitu bukti fisik (tangible), keandalan (relliability), cepat tanggap (responsiveness), jaminan (assurance), dan kepedulian (emphaty).

\section{Saran}

1. Dilihat dari hasil tersebut, maka pihak Bank Mandiri Cabang Manado Dotulolong Lasut untuk memperhatikan dan meningkatkan variabel jaminan dan kepedulian demi kepuasan nasabah KUR.

2. Perlu penelitian lanjutan untuk mengetahui hasil lebih lanjut mengenai kualitas pelayanan pada PT. Bank Mandiri (Persero) Tbk KC Manado Dotulolong Lasut. 


\section{DAFTAR PUSTAKA}

Bandu, M. Y. 2013. Pengaruh Kualitas Pelayanan Terhadap Kepuasan Pelanggan pada PT. PLN (Persero) Rayon Makassar Barat. Skripsi Jurusan Ilmu Administrasi Fakultas Ilmu Sosial dan Ilmu Politik Universitas Hasanuddin. Makassar.

Hardiyati, R. 2010. Analisis Pengaruh Kualitas Pelayanan Terhadap Kepuasan Konsumen Menggunakan Jasa Penginapan (Villa) Agrowisata Kebun Teh Pagilaran. Skripsi Fakultas Ekonomi Universitas Diponegoro. Semarang.

Yulinda. Analisis Pengaruh Kualitas Pelayanan Terhadap Kepuasan Nasabah Kredit Sumut Sejahtera I Pada PT. Bank Sumut Area Utama Medan.Jurnal Ekonom, Vol. 16 No. 1, Januari 2013. 